\title{
Return On Assets Sebagai Pengukuran Perputaran Modal Kerja dan Piutang PT AKR Corporindo Tbk
}

\author{
Lisdawati $^{1)}$, Faisal Ardiansyah ${ }^{2)}$ \\ Fakultas Ekonomi, Universitas Pamulang ${ }^{1,2}$ \\ dosen02115@unpam.ac.id \\ faisalardiansyah026@gmail.com
}

\begin{abstract}
Abstrak
Kinerja keuangan dapat menjadi masa depan atau prospek yang potensi perkembangannya sangat baik untuk pertumbuhan perusahaan. Modal kerja menjadi persoalan tersendiri dan sangat fundamental yang sering dihadapi oleh manajer perusahaan dalam pengelolaan ekuitas dan asetnya sementara Piutang yang menjadi bagian dari komponen modal kerja yang memiliki perputaran atau siklus yang berhubungan dengan penjualan atas komoditas, aliran kas, dan penerimaan kas, dimana perputarannya menggambarkan kondisi keuangan yang baik. Populasi penelitian menggunakan data laporan keuangan pada PT AKR Corporindo Tbk tahun 2005-2019. Tujuan penelitian ini secara spesifik mengkaji dan membuktikan secara empiris pengukuran Modal Kerja dan Perputaran Piutang dan dampaknya pada Return On Assets. Analisis data menggunakan analisis regresi berganda dengan perangkat lunak Statistic/Data Analysis STATA MP14 Version. Hasil penelitian ini menunjukkan bahwa Perputaran modal kerja dan perputaran piutang tidak berdampak pada meningkatnya Return On Assets baik secara parsial maupun simultan. Kontribusi Return On Assets dipengaruhi sebesar 16,88 persen atas faktor Perputaran Modal Kerja, Perputaran Piutang serta Ukuran Perusahaan sebagai variabel kontrol.
\end{abstract}

\section{Kata Kunci: Piutang, Return On Assets, Perputaran Modal Kerja}

\begin{abstract}
Financial performance can be a future or prospect whose development potential is very good for company growth. Working capital is a separate and fundamental problem that company managers often face in managing equity and assets. In contrast, Receivables, which are part of the working capital component, have a turnaround or cycle related to the sale of commodities, cash flow, and cash receipts. The turnover describes good financial condition. The study population used financial statement data at PT AKR Corporindo Tbk in 2005-2019. The purpose of this research is to specifically examine and prove the measurement of Working Capital and Accounts Receivable Turnover and its impact on Return On Assets empirically. Data analysis used multiple regression analysis with Statistic / Data Analysis software STATA MP14 Version. This study indicates that the turnover of working capital and accounts receivable turnover does not increase Return on Assets either partially or simultaneously. The Return On Assets contribution is influenced by 16.88 percent of the Working Capital Turnover, Accounts Receivable Turnover, and Company Size factors as control variables.
\end{abstract}

Keywords: Receivables, Return On Assets, Working Capital

\section{PENDAHULUAN}

Kinerja keuangan dapat menjadi masa depan atau prospek yang potensi perkembangannya sangat baik untuk pertumbuhan perusahaan. Dengan menggunakan asumsi pasar yang efisien, investor dapat melihat sinyal positif ini dan merevisi tingkat ekuitas terendah dalam penilaian harga yang harga lebih tinggi dalam komponen laba (Pasupati, 2020). Laba yang maksimal menjadi tujua utama perusahaan dalam aktivitas operasionalnya. Upaya peningkatan kinerja keuangan dalam aktivitas manajemen mencakup aspek perencanaan, pengelolaan dan aktivitas pengendalian sumberdaya secara optimal menjadi sangat peenting dalam rangka efisiensi dan 
efektivitas output dari tujuan perusahaan (Gunawan, 2012). Pengukuran kinerja pada akhir periode perusahaan untuk menilai keuangan perusahaan berupa analisis akuntansi neraca atau laporan posisi keuangan dan serta laporan laba rugi dalam konteks aktivitas perusahaan, hal ini menjadi pokok input dalam data akuntansi yang memuat informasi keuangan (Ramadhan \& Syarfan, 2016).

Menurut Gheorghe Lepădatu (2010), akuntansi adalah aktivitas mengukur, menerjemahkan, atau membantu manajer, pemegang saham yang memberikan atas kepastian serta pengambil keputusan eksternal lainnya dalam pengalokasian sumberdaya lembaga pemerintah maupun organisasi (Isfani, Dewi, \& Husain, 2019). Sumberdaya ini sebagai informasi entitas bisnis yang dialokasikan pada akhirnya harus diukur untuk menggambarkan kinerja keuangan. Sumberdaya data ini digunakan sebagai input dalam proses akuntansi dalam menghasilkan laporan keuangan. Menurut S. Titman, A.J. Keown, dan J.D. Martin (2013) mendefinisikan rasio keuangan sebagai penyajian kembali data akuntansi dalam hal waktu dengan menggunakan pengukuran CR, TATO, DER, ROE, and EPS (Husain, Pasupati, \& Quintania, 2020). Laporan keuangan selalu dipercaya dan diandalkan dalam menggambarkan kinerja perusahaan, seperti kinerja bank yang dievaluasi dengan CAMELS oleh Bank Indonesia tahun 1991 dan dirilis melalui Peraturan Bank Indonesia atau PBI No.6/10/PBI/2004 yang singkatan dari masingmasing kata yakni capital, asset quality, management, earning, liability, dan sensitivity market to risk. Keseluruhan komponen di atas sangat menentukan besaran modal pada bank, sehingga kinerja bank dapat dipengaruhi oleh adanya kepercayaan masyarakat (Mailinda, 2018).

Modal kerja menjadi persoalan tersendiri dan sangat fundamental yang sering dihadapi oleh manajer perusahaan dalam pengelolaan ekuitas dan asetnya. Menurut Kasmir (2016:314), modal kerja dapat didefinisikan sebagai pengukuran salah satu rasio atau penilaian efektivitas perusahaan berdasarkan perputarannya selama periode tertentu dalam menjaga kelangsungan perusahaan (Gustiady, 2018). Pengukuran tingkat efisiensi itu sendiri dapat didasarkan pada konsep akuntansi yang dapat diukur dengan beberapa rasio keuangan perusahaan. Efisiensi dapat diklasifikasikan berdasarkan total aset perusahaan, baik berdasarkan pendapatan operasional maupun laba bersih, efisiensi berdasarkan modal sendiri, dan efisiensi berdasarkan pendapatan operasi dan laba bersih (Lisdawati \& Khair, 2020). Lebih lanjut, upaya peningkatan efisiensi dan efektivitas transaksi saham di pasar modal juga hendaknya dianalisis dan memperhatikan aspek perilaku investor karena berdampak pada meningkatnya kinerja penjualan saham (Sakir \& Zainul, 2019).

Kinerja perusahaan dalam aktivitas sehari-hari untuk memperoleh penerimaan kas cenderung melakukan transaksi secara tunai. Kas ini digunakan sebagai pembiayaan untuk memperoleh penerimaan kas pada transaksi selanjutnya. Di sisi lain, pembayaran secara kredit umumnya konsumen akan lebih disukai karena sistem pembayarannya dapat ditunda (Triatika P., Lestari, \& Rasyidi, 2016). Piutang biasanya memiliki signifikansi dari komponen aktiva lancar perusahaan. Penjualan kredit merupakan pengakuan dari piutang dan menghasilkan tagihan. Penjualan dalam bentuk barang atau jasa inilah akan menghasilkan transaksi umum berupa piutang.

Piutang usaha memiliki jangka waktu yang relatif pendek yang akan diperkirakan tertagih pada 30 hari atau 60 hari, atau lainnya (En \& Sunarko, 2011). Piutang yang menjadi bagian utama dari komponen modal kerja yang memiliki turnover atau siklus yang berhubungan dengan penjualan atas komoditas, aliran kas, dan penerimaan kas, dimana perputarannya menggambarkan kondisi keuangan yang baik (Chakiki \& Jawoto, 2016). Pengelolaan piutang ini dapat ditinjau dari tingkat perputaran (turnover) atas piutangnya. Turnover ini diukur dengan basis panjang atau pendeknya berdasarkan ketentuan waktu yang diatur dalam perjanjian kredit, seluruh organisasi menggunakan pengukuran BOPO (biaya operasional pendapatan operasional) ini untuk mengukur kinerja perusahaan dengan dimensi profitabilitas (Khristiana \& Sapariyah, 2016). Kondisi ini dapat dikatakan jumlah modal yang diinvestasikan dalam satu periode (tahun) atas tingkat perputaran piutangnya.

Laba yang diperoleh dari aktivitas modal dan aktivitas rutin di atas bermuara kepada aspek kinerja perusahaan yang dirangkum pada output laporan laba rugi yaitu laba bersih tahun berjalan. Output ini biasa digunakan sebagai pembilang dalam mengukur profitabilitas atau dengan kata lain suksesnya atau produktivitas dari aktivitas perusahaan. Profitabilitas dikalkulasikan salah satunya melalui komparasi laba yang diperoleh dalam periode berjalan dengan besarnya kepemilikan modal perusahaan tertentu (Rachmaniah, 2017). Jadi profitabilitas merupakan salah satu cara terbaik untuk mengukur keefektifan perusahaan dalam menghasilkan laba. Salah satu proksi yang digunkana perusahaan untuk menghitung profitabilitas yaitu return on assets atau (ROA). Proksi ini digunakan sebagai tools untuk menghasilkan informasi kinerja perusahaan dalam capaian laba, maka profitabilitas perusahaan harus 
diukur, misalnya menggunakan proksi margin laba (profit margin) atau dengan ROA (Sanjaya \& Rizky, 2018; Priyanto, 2019). Return on assets dapat dikatakan sebagai ukuran atas kemampuan dalam mencapai laba tertentu dengan semua kepemilikan aset perusahaan (Sutrisno, 2013, hal. 229). Profitabilitas dengan proksi ROA lebih baik karena menggabarkan kinerja atau daya tarik bisnis. ROA merupakan komparasi faktor margin laba dengan total asset turnover, jika faktor salah satu diantaranya meningkat maka ROA juga akan meningkat yang menunjukkan kinerja perusahaan semakin baik (Lisdawati, 2020).

PT AKR Corporindo Tbk (yang selanjutnya disebut 'perusahaan'), dikenal sebagai badan usaha yang bergerak pada bidang penyedia supply chain, jasa logistik, dan infrastruktur yang cukup ternama di Indonesia. Perusahaan beroperasi tidak hanya di Indonesia melainkan juga di Tiongkok. Salah satu transformasi perusahaan melalui jaringan (network) menjadi distributor swasta skala besar untuk bahan kimia dasar dan BBM di Indonesia. Perusahaan yang telah menjadi mitra Pemerintah dalam menyalurkan BBM dalam program Satu Harga yang telah terbangun 162 titik. Berdasarkan data tahun 2017 dan 2018, perusahaan telah 9 (sembilan) titik diantaranya oleh dibangun oleh PT AKR Corporindo Tbk sementara PT Pertamina (Persero) membangun 112 lembaga penyalur di Pulau Rote (Kementerian ESDM, 2019).

Penugasan $\mathrm{BOH}$ Migas atas pemasok BBM bersubsidi kembali diberikan dengan melibatkan anak perusahaan yaitu PT Usaha Era Pratama Nusantara dengan PT Berlian Jsa Terminal Indonesia atas kerjasamanya yang akan menghasilkan nilai tambah (value added) pada kawasan industri dan integrasi pelabuhan 'Java Integrited Industrial and Ports Estates (JIPPE) yang berlokasi di Gresik, Jawa Timur (AKR, 2019). Nilai tambah ini tentunya menjadi sangat penting bagi perusahaan untuk menuai keberhasilan dan mempertahankan going-concern. Kondisi ini tidak terlepas dari adopsi penggunaan teknologi dalam membentuk sistem teknologi informasi dalam mempercepat pertumbuhan bisnis, integrasi sistem data real time serta keamanan data (AKR, 2019). Perusahaan akan dapat meningkatkan resource menggunakan perangkat yang terkomputerisasi sebagai dasar manajemen dalam pengambilan keputusan seperti halnya dengan Enterprise Resource Planning System (ERPS) (Husain T. , 2017). Strategi ini melekat dan diterjemahkan dalam platform ERP perusahaan dalam aplikasi bisnis. Tujuan pokok dalam perolehan kinerja perusahaan adalah memperoleh kentungan maksimal dan pengembangan usaha kedepannya. Laporan untuk menghitung tingkat perputaran modal kerja dan perputaran piutang terhadap Return On Asset (ROA) pada PT. AKR Corporindo Tbk selama 15 tahun adalah sebagai berikut:

Tabel 1. Data Penjualan, Perputaran Modal Kerja dan Perputaran Piutang (Tahun 2005-2019)

\begin{tabular}{rrrr}
\hline Tahun & $\begin{array}{c}\text { Penjualan } \\
\text { (Jutaan Rp.) }\end{array}$ & $\begin{array}{r}\text { Perputaran } \\
\text { Modal Kerja } \\
\text { (kali) }\end{array}$ & $\begin{array}{c}\text { Perputaran } \\
\text { Piutang } \\
\text { (kali) }\end{array}$ \\
\hline 2005 & 282,80 & 1,26 & 0,81 \\
2006 & 397,00 & 2,86 & 0,89 \\
2007 & $5.894,75$ & 22,80 & 9,38 \\
2008 & $9.476,13$ & 404,82 & 11,20 \\
2009 & $8.959,84$ & $-77,13$ & 8,14 \\
2010 & $10.320,71$ & 12,33 & 7,78 \\
2011 & $10.805,95$ & 13,63 & 10,74 \\
2012 & $21.673,95$ & 9,54 & 8,16 \\
2013 & $22.337,93$ & 19,78 & 6,01 \\
2014 & $22.468,33$ & 43,49 & 5,23 \\
2015 & $19.764,82$ & 8,19 & 5,36 \\
2016 & $15.212,59$ & 9,65 & 5,42 \\
2017 & $18.287,94$ & 5,40 & 6,95 \\
2018 & $23.548,14$ & 7,35 & 6,63 \\
2019 & $21.702,64$ & 10,51 & 4,97 \\
\hline
\end{tabular}

(Sumber: Input Data Peneliti, 2020)

Tabel di atas memberikan informasi atas peningkatan nilai penjualan dalam satu dekade sejak tahun 2005 hingga tahun 2014 yaitu dari Rp282.80,- juta menjadi Rp22.468,33,- juta. Peningkatan perputaran modal kerja hanya meningkat cukup signifikan di tahun 2008 sebesar 404,82 kali dan turun secara signifikan di tahun 2009 menjadi minus 77,13 kali, dan berfluktuasi kembali sejak tahun 2010 sebesar 12,33 hingga tahun 2014 sebesar 43,49 sementara perputaran piutang juga hanya meningkat cukup signifikan di tahun 2008 sebesar 11,2 kali dan berfluktuasi kembali sejak tahun 2009 hingga pada tahun 2014 menjadi 5,23 kali. Data ini memberikan gambaran bahwa perusahaan sejak 2010, 2012 cukup efektif dalam mengelola tetapi tidak efisien dalam mengelola piutangnya. Peningkatan nilai penjualan dalam 5 tahun terakhir sejak tahun 2015 sebesar Rp19.764.88,- juta dan berfluktuasi hingga tahun 2019 yaitu menjadi Rp21.702,64,- juta. Peningkatan perputaran modal kerja berfluktuasi dan peningkatan yang tidak signifikan hingga di tahun 2019 sebesar 
58 Coopetition, Vol XII, Nomor 1, Maret 2021, 55 - 64

(E-ISSN : 2615-4978, P-ISSN : 2086-4620)

10,51 kali sementara perputaran piutang juga hanya meningkat yang tidak terlalui signifikan sejak tahun 2015 sebesar 5,36 kali hingga tahun 2019 menjadi 4,97 kali. Data ini memberikan gambaran bahwa perusahaan dalam kurum 5 (lima) tahun terakhir sejak 2014 cukup efektif dalam mengelola perputaran piutangnya.

Penelitian ini dilatarbelakangi dari beberapa temuan riset terdahulu: 1) Studi dalam menganalisis kinerja keuangan tahun 2009-2011 pada PT Fajar Surya Wisesa, Tbk dengan pengukuran rasio lancar, rasio cepat, rasio masing-masing perputaran aktiva tetap, hutang, dan pengembalian total aktiva serta pengembalian atas ekuitas. Hasil penelitian menunjukkan bahwa berdasarkan likuiditas (rasio lancar dan cepat) atas kinerja keuangan tergambar dalam kondisi perusahaan yang kurang begitu baik, manajemen aktiva tergambar dengan kondisi yang cukup baik (rasio perputaran aktiva tetap), manajemen hutang tergambar dengan kondisi yang kurang begitu baik (rasio hutang), dan profitabilitas (pengembalian atas aktiva tetap dan pengembalian atas ekuitas) atas kinerja keuangan tergambar dalam kondisi yang kurang baik (Gunawan, 2012). 2) Studi tentang pengukuran dan analisis laporan keuangan pada kinerja perusahaan tahun 2012-2014 di PT. Ricky Kurniawan Kertapersada (Makin Group) Jambi. Hasil penelitian menunjukkan bahwa berdasarkan rasio likuiditas yang terdiri dari rasio kas, rasio cepat, dan rasio lanncar) atas kinerja keuangan yang baik dan mengalami peningkatan serta rasio cepat yang terus bertambah, rasio solvabilitas tergambar dengan kondisi yang menurun (rasio utang terhadap total aktiva dan total modal), return on assets tergambar dengan kondisi yang kurang begitu baik karena hasil penjualan yang kurang optimal dalam rangka perolehan laba bersih, dan rasio aktivitas (perputaran total aktiva atas volume penjualan, perputaran total aktiva atas penggunaan modal) atas kinerja keuangan tergambar dalam kondisi yang cukup produktif tetapi tidak begitu baik atas perputaran aktiva tetapnya (Ramadhan \& Syarfan, 2016). 3) Studi dalam menganalisis modal kerja tahun 2010-2014 pada PT. Berau Coal Energy Tbk dengan perputaran masing-masing modal kerja, persediaan dan kas serta profitabilitas dengan pengukuran ROE. Hasil penelitian menunjukkan bahwa dari analisis perputaran persediaan yang memprediksi profitabilitas (ROE) sementara perputaran modal kerja dan perputaran kas tidak mengikuti profitabilitas (ROE). Di samping itu, ketiga proksi perputaran (turnover) di atas secara simultan tidak berpengaruh terhadap profitabilitas (Rachmaniah, 2017). 4) Studi dalam menganalisis profitabilitas sebagai penilaian kinerja keuangan pada PT. Taspen (Persero) Medan dengan faktor ROA dan ROE. Hasil penelitian menggambarkan penilaian kinerja keuangan tidak mampu mencapai laba atas kepemilikan ekuitas karena ROA dan ROE cenderung mengalami penurunan yang disebabkan menurunnya penjualan yang berdampak pada laba perusahaan (Sanjaya \& Rizky, 2018). 5) Studi atas profitabilitas yang dipengaruhi leverage, likuiditas dan ukuran perusahaan tahun 2015-2017 pada BNI Syariah. Hasil penelitian menunjukkan bahwa profitabilitas dipengaruhi secara positif oleh leverage dan likuiditas secara signifikan sementara ukuran perusahaan berpengaruh secara positif namun tidak signifikan. Ketiga variabel di atas secara simultan berpengaruh signifikan (Mailinda, 2018). 6) Studi dalam menganalisis pengelolaan piutang dengan perputaran piutang, rata-rata periode penagihan, rasio tunggakan dan penagihannya tahun 2013-2017 pada PT. Nippon Indosari Corpindo Tbk. di Kota Makassar. Hasil penelitian menunjukkan bahwa dari analisis perputaran piutang berflutuasi sementara rata-rata periode penagihan cukup efektif. Rasio tunggakan kurang baik dibandingkan periode sebelumnya dan rasio penagihan tergolong baik (Nginang, 2019).

Data dan trend ketiga konstruk di atas memberikan gambaran bahwa pengukuran modal kerja dan perputaran piutang memiliki dampak langsung atas ROA PT. AKR Corporindo Tbk yang memiliki pertumbuhan yang cukup signifikan. Atas fenomena spesifik ini dan temuan penelitian terdahulu ini merumuskan pertanyaan berikut ini: (1) Bagaimana pengaruh pengukuran Modal Kerja dan dampaknya pada ROA; (2) Bagaimana pengaruh pengukuran Perputaran Piutang dan dampaknya pada ROA; dan (3) Bagaimana pengaruh pengukuran Modal Kerja dan Perputaran Piutang dan dampaknya pada ROA?.

Tujuan penelitian ini secara spesifik mengkaji dan membuktikan secara empiris pengukuran Modal Kerja dan Perputaran Piutang dan dampaknya pada Return On Assets. Perbedaan penelitian ini yaitu periode penelitian yang lebih panjang digunakan yaitu selama tahun 2005-2019 serta menggunakan salah satu perusahaan pada jenis Industri Manufaktur Sektor Kimia dan Dasar yang terdaftar di Bursa Efek Indonesia yaitu PT AKR Corporindo Tbk. Pentingnya penelitian ini dilakukan antara lain: 1) Menambah kajian manajemen keuangan yang secara spesifik membahas topik kinerja perusahaan dalam konteks pengukuran Return On Asset dan faktor-faktor penentunya; 2) Meyakinkan dengan lebih kepada investor agar tetap berfokus pada proksi Return On Asset sebagai output dan dasar pengambilan keputusan investasi; dan 3) Perusahaan dapat 
mengevaluasi kebijakan keuangan ini sebagai pertimbangan dalam perolehan informasi keputusan bisnis.

\section{TINJAUAN PUSTAKA}

\section{A. Return On Assets}

Return On Assets (ROA) yang dikutip dari Kasmir (2016:201), yaitu rasio yang digunakan dalam perusahaan untuk mengukur profitabilitas yang hasilnya ditunjukkan pada kemampuan perusahaan atas jumlah aset yang digunakan. Menurut Irham Fahmi (2017:98), ROA yaitu pengembalian keuntungan dari investasi yang ditanamkan dengan harapan pengukuran kepemilikan aset perusahaan. Rasio profitabilitas mengukur efektifitas kinerja manajemen berdasarkan perolehan imbal hasil atas investasi dan penjualan. Profitabilitas juga berperan bagi perusahaan dalam jangka panjang dalam goingconcern perusahaan, karena proksi ini sebagai tools untuk menilai prospek profitabilitas perusahaan di masa mendatang (Sanjaya \& Rizky, 2018).

\section{B. Perputaran Modal Kerja}

Menurut Kasmir (2016:201), perputaran modal kerja dapat didefinisikan sebagai rasio untuk menilai atau mengukur efektif modal kerja perusahaan. Menurut Irham Fahmi (2017:100). Modal kerja yaitu investasi perusahaan terhadap aset jangka pendek seperti kas, piutang, sekuritas maupun persediaan. Pengelolaan modal kerja dianggap berhasil jika modal kerja tidak menimbulkan kelebihan atau kekurangan serta sesuai standar yang ditetapkan, sehingga dapat memberikan hasil yang memuaskan (Rachmaniah, 2017). Kinerja perusahaan akan baik jika modal kerja yang diinvestasikan dalam bentuk piutang jumlahnya kecil, artinya kinerja pengelolaan piutang otomatis akan berjalan dengan baik. Peningkatan aset lancar menunjukkan bahwa perusahaan berhasil melunasi hutang jangka pendeknya yang berdampak pada berkurangnya utang jangka pendek dan menurunnya proporsi struktur pendanaan perusahaan (Sunardi, Husain, \& Kadim, 2020).

\section{Perputaran Piutang}

Menurut Kasmir (2016:176), perputaran piutang yaitu salah satu rasio penilaian atas efektifitas dan waktu atau lamanya penagihan piutang atau besarnya dana yang diinvestasikan dalam piutang yang berotasi dalam satu periode. Irham Fahmi (2017) menambahkan bahwa piutang menggambarkan pembayaran yang tidak dilakukan secara tunai namun bertahap oleh perusahaan. Piutang yang khususnya berasal utang lancar sangat diperlukan untuk mendukung komponen aset lancar perusahaan.
Piutang berasal dari aktivitas seperti sewa dan bunga mengacu pada janji lisan dengan nilai yang jatuh tempo yang bersumber dari penjualan secara kredit (Nginang, 2019). Menurut S. Titman, A.J. Keown, dan J.D. Martin (2013), perputaran piutang dianggap akan berhasil jika perusahaan mampu secara cepat dan tepat waktu dalam mengeksekusi atau mencairkan asetnya yang bersumber dari piutang usaha dan persediaan yang dikonversi menjadi uang tunai yang diuji dengan beberapa komponen atas kelayakannya pada liquidity ratio (Zailani, Husain, \& Budiyantara, 2020).

Hasil penelitian Agun Gunawan (2012) menunjukkan bahwa likuiditas (rasio lancar dan rasio cepat) tergolong kurang baik sementara rasio lancar, rasio kas, dan rasio cepat dalam kondisi yang cukup produktif tetapi tidak pada perputaran aktiva tetapnya (Ramadhan \& Syarfan, 2016). Modal kerja atas perputarannya tidak mampu memprediksi profitabilitas dengan proksi ROE dan juga perputaran kas (Rachmaniah, 2017). Working capital turnover dalam proksi ini memberikan gambaran bahwa semakin tinggi perputaran ini maka berdampak atas peningkatan kinerja keuangan yaitu profitabilitasnya. Gap ini melandasari peneliti untuk merumuskan hipotesis alternatif berikut:

H1: Perputaran modal kerja berdampak pada meningkatnya Return On Assets

Hasil penelitian Riska Mailinda (2018) menunjukkan bahwa likuiditas industri perbankan dengan proksi financil to deposit ratio (FDR) yang dibuktikan dengan signifikansinya terhadap profitabilitas (ROA). Fluktuasi yang terjadi atas perputaran piutang perusahaan atau dengan kata lain kurang baiknya kinerja piutang untuk memulihkan atau percepatan dalam rangka memperoleh keuntungan (Nginang, 2019). Receivable turnover mengindikasikan bahwa semakin cepat piutang kembali menjadi modal atau kas maka berdampak pada kinerja keuangan perusahaan yaitu profitabilitasnya. Gap ini melandasari peneliti untuk merumuskan hipotesis alternatif berikut:

H2: Perputaran piutang berdampak pada meningkatnya Return On Assets

Hasil penelitian Rachmaniah (2017), perputaran modal kerja, perputaran persediaan dan perputaran kas tidak memiliki pengaruh atas profitabilitas dengan proksi ROE sementara secara simultan. Leverage, likuiditas dan ukuran perusahaan berpengaruh atas profitabilitas secara simultan dengan proksi ROA (Mailinda, 2018). Gap ini melandasari peneliti untuk merumuskan hipotesis alternatif berikut: 
60 Coopetition, Vol XII, Nomor 1, Maret 2021, 55 - 64

(E-ISSN : 2615-4978, P-ISSN : 2086-4620)

H3: Perputaran modal kerja dan perputaran piutang berdampak pada meningkatnya Return On Assets

Pernyataan sementara atas sesuatu yang dianggap benar yaitu hipotesis. Secara kuantitatif, hipotesis adalah nilai parameter yang dianggap benar dalam waktu sementara (Supranto \& Limakrisna, 2019, hal. 33). Parameter ini hendaknya diidentifikasi yang dituangkan ke dalam sub atau turunan pada suatu model. Logika IPO (input-process-output) dan kombinasi model kausal dapat digunakan merumuskan hipotesis alternatif (Sani, Pusparini, R., Khristiana, Zailani, \& Husain, 2020). Logika di atas dalam istilah penelitian akademis berupa paradigma atau kerangka berpikir (framework of thinking) yang diturunkan menjadi model penelitian.

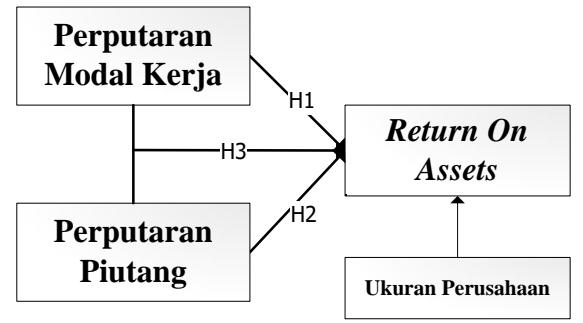

Gambar 1. Model Penelitian

(Sumber: Peneliti, 2020)

\section{METODE PENELITIAN}

Penelitian ini menggunakan jenis kausalitas dengan pendekatan kuantitatif. Populasi penelitian menggunakan data laporan keuangan pada PT AKR Corporindo Tbk tahun 2005-2019. Sampel adalah sebagian elemen dari populasi, $\mathrm{n}=$ banyaknya elemen sampel. Teknik sampling menggunakan sensus karena melibatkan elemen populasi yang satu per satu diteliti (Supranto \& Limakrisna, 2019, hal. 57). Jumlah sampel adalah 15 data pengamatan tahun 2005-2019 atas (tiga) variabel yaitu Return On Assets, Perputaran Modal Kerja, dan Perputaran Piutang. Teknik penelitian ini berupa studi dokumentasi yang mengambil data-data sekunder berupa data laporan keuangan pada PT AKR Corporindo Tbk tahun 20052019 yang diakses melalui www.idx.co.id dan situs atau website resmi perusahaan. Analisis data menggunakan analisis regresi berganda dengan perangkat lunak Statistic/Data Analysis STATA MP14 Version. Stata merupakan salah satu program yang dapat dimanfaatkan dalam analisis perhitungan kuantitatif dan mempunyai keunggulan tersendiri (Santosa, 2020, hal. 1). Analisis ini menggunakan persamaan berikut:

$$
\mathrm{Y}=\alpha+\beta 1 \mathrm{X} 1+\beta 2 \mathrm{X} 2+\beta 3 \mathrm{C}+\mathrm{e} \rightarrow(1)
$$

Dimana :

$$
\begin{aligned}
\mathrm{Y}= & \text { Return On Assets } \\
\alpha= & \text { Konstanta } \\
\beta 1= & \text { Koefisien variabel independen Perputaran } \\
& \text { Modal Kerja (X1) } \\
\beta 2= & \text { Koefisien variabel independen Perputaran } \\
& \text { Piutang (X2) } \\
\beta 3= & \text { Koefisien variabel kontrol Ukuran Perusahaan } \\
& (\mathrm{C}) \\
\mathrm{e}= & \text { error term }
\end{aligned}
$$

Variabel operasional yang digunakan meliputi:

A. Variabel dependen:

Return On Assets (Y) didefinisikan sebagai rasio profitabilitas untuk menggambarkan efisiensi operasi perusahaan dalam menghasilkan keuntungan dengan rumus:

$$
\begin{aligned}
R O A= & \frac{\text { Net Income after } T a x}{\text { Total Assets }} \rightarrow(2) \\
& \text { Sumber: (Gitman \& Zutter, 2015, hal. 81; } \\
& \text { Brigham \& Houston, 2015) }
\end{aligned}
$$

B. Variabel independen:

Perputaran Modal Kerja (X1) atau working capital turnover digunakan untuk melihat seberapa banyak modal kerja berputar dalam satu periode dengan rumus:

$$
\begin{gathered}
\text { Perputaran Modal Kerja }=\frac{\text { Penjualan Bersih }}{\text { Modal Kerja }} \rightarrow(3) \\
\text { Sumber: }(\text { Kasmir, 2016, hal. 314) }
\end{gathered}
$$

Perputaran Piutang (X2) atau receivable turnover digunakan untuk melihat penagihan piutang berputar dalam satu periode dengan rumus:

$$
\begin{gathered}
\text { Perputaran Piutang }=\frac{\text { Penjualan Kredit }}{\text { Rata-Rata Piutang }} \rightarrow(4) \\
\text { Sumber: (Kasmir, 2016, hal. 176) }
\end{gathered}
$$

C. Variabel kontrol:

Ukuran Perusahaan (C) difungsikan sebagai variabel kontrol dalam model penelitian dengan rumus:

$$
\begin{gathered}
\text { Ukuran Perusahaan }=\text { Log Total Aset } \rightarrow(5) \\
\text { Sumber: }(\text { Murhadi, 2015) }
\end{gathered}
$$

\section{HASIL DAN PEMBAHASAN}

Kalkulasi penelitian ini menggunakan Microsoft Excel dan data sekunder yang digunakan untuk mengolah data-data laporan keuangan tahunan PT 
AKR Corporindo Tbk yaitu Neraca dan Laporan Laba Rugi yang telah diaudit dan publikasikan selama 15 tahun berturut-turut dari tahun 2005-2019.

\section{Tabel 2. Hasil Statistik Deskriptif}

\begin{tabular}{ccccc}
\hline Variabel & Mean & Std. Dev. & Min & Max \\
\hline $\mathbf{Y}$ & 0,055 & 0,014 & 0,034 & 0,082 \\
$\mathbf{X 1}$ & 32,97 & 105,94 & $-77,13$ & 404,82 \\
$\mathbf{X 2}$ & 6,511 & 3,002 & 0,81 & 11,20 \\
\hline $\mathbf{C}$ & 12,942 & 0,337 & 12,297 & 13,331 \\
\hline
\end{tabular}

(Sumber: Perhitungan Output Olahdata, 2020)

Tabel di atas memberikan informasi atas nilai Return On Assets (Y) yang berkisar antara 3,4 persen hingga 8,2 persen dengan rata-rata sebesar 5,5 persen. Nilai Perputaran Modal Kerja (X1) yang berkisar antara minus 77,13 kali hingga 404,82 kali dengan rata-rata sebesar 32,97 kali. Nilai Perputaran Piutang (X2) yang berkisar antara minus 0,81 kali hingga 11,20 kali dengan rata-rata sebesar 6,51 kali.

Tabel 3. Hasil Uji Normalitas (Shapiro-Wilk W Test)

\begin{tabular}{ccccc}
\hline & Nilai W & Nilai V & Nilai $\mathbf{Z}$ & Prob>z \\
\hline RES & 0,97430 & 0,498 & $-1,377$ & 0,91581 \\
\hline
\end{tabular}

(Sumber: Perhitungan Output Olahdata, 2020)

Tabel di atas memberikan informasi atas nilai residual pada model regresi sebesar 0,91581 (lebih besar dari $0,05)$, artinya nilai probabilitas telah memenuhi asumsi normalitas data.

Tabel 6. Uji Regresi Linier Berganda (Uji F dan Uji t)
Tabel 4. Hasil Uji Heteroskedastisitas (Breusch-Pagan)

\begin{tabular}{ccc}
\hline & chi2(1) & Prob>chi2 \\
\hline Fitted Values of $\mathbf{Y}$ & 2,03 & 0,1546 \\
\hline \hline
\end{tabular}

(Sumber: Perhitungan Output Olahdata, 2020)

Tabel di atas memberikan informasi atas nilai probabilitas Chi-Square sebesar 0,1546 (lebih besar dari 0,05$)$, artinya model regresi tidak mengandung heteroskedasisitas.

Tabel 5. Hasil Uji Multikolinearitas VIF

\begin{tabular}{ccc}
\hline Variabel & VIF & 1/VIF \\
\hline X1 & 1,31 & 0,762974 \\
X2 & 1,28 & 0,778903 \\
\hline $\mathbf{C}$ & 1,12 & 0,892588 \\
\hline
\end{tabular}

(Sumber: Perhitungan Output Olahdata, 2020)

Tabel di atas memberikan informasi atas masingmasing nilai VIF kurang dari 10, yang berarti tidak adanya masalah multikolinearitas antar variabel independen dan variabel kontrol.

Hasil uji asumsi klasik di atas telah memenuhi persyaratan asumsi klasik yang mana analisis linier bagus dan memiliki bias yang rendah atau disebut dengan Best Linier Unbiased Estimator (BLUE) (Santosa, 2020, hal. 41). Oleh karenanya, dapat dilanjutkan dengan hasil persamaan regresi dan pengujian hipotesis.

Uji hipotesis merupakan analisis untuk mengetahui apakah hipotesis ditolak atau diterima yang secara spesifik menggunakan pengujian (T-stat) (Sani, Wiliani, \& Husain, 2019). Hasil uji hipotesis dilakukan melalui uji regresi atas nilai $\mathrm{F}$ dan nilai $\mathrm{t}$ yang dirangkum pada beberapa pengujian berikut ini:

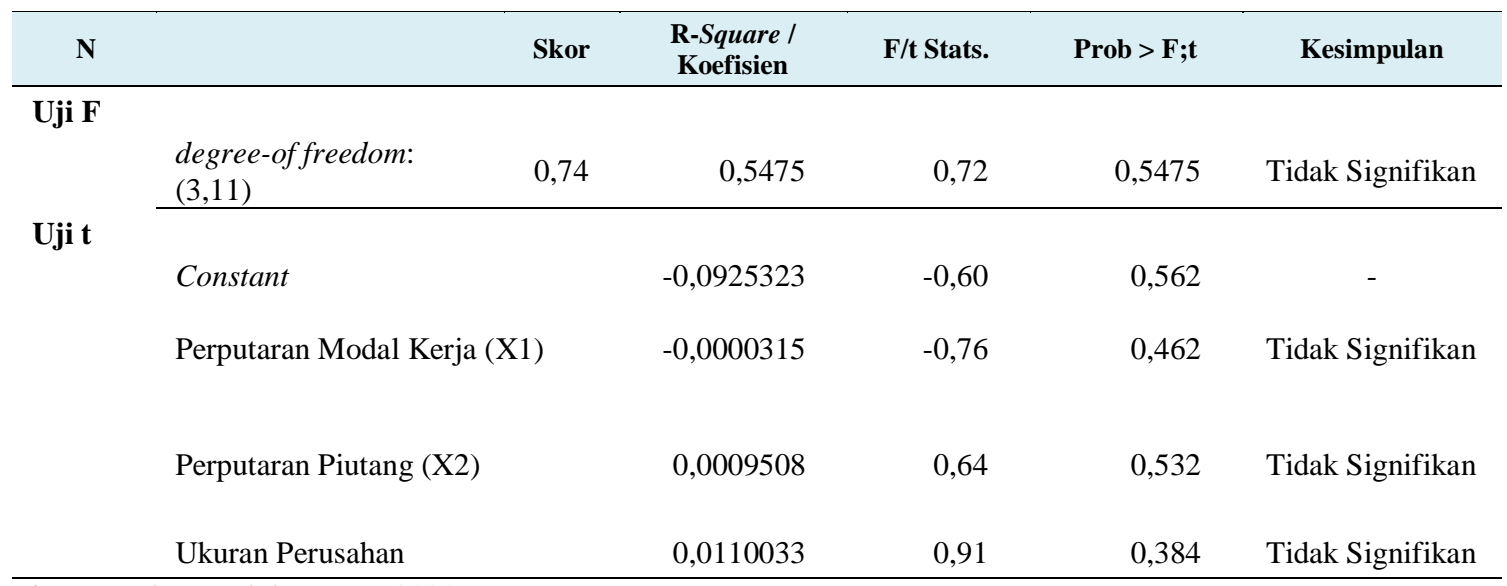

(Sumber: Hasil Pengolahan Data 2020) 
62 Coopetition, Vol XII, Nomor 1, Maret 2021, 55 - 64

(E-ISSN : 2615-4978, P-ISSN : 2086-4620)

Tabel di atas memberikan informasi untuk menjelaskan hasil persamaan regresi berikut ini:

$$
\begin{gathered}
\mathrm{Y}=-0,0925323-0,0000315 \mathrm{X} \\
+0,0009508 \mathrm{X} 2+0,0110033
\end{gathered}
$$

Hasil regresi di atas menghasilkan nilai konstan sebesar minus 0,0110033, artinya jika X1 yaitu Perputaran Modal Kerja dan X2 yaitu Perputaran Piutang serta Ukuran Perusahaan dianggap konstan, maka besarnya Return On Assets (ROA) adalah minus 9,25 persen. Perputaran Modal Kerja sebesar minus 0,0000315 yang berarti jika variabel ini mengalami peningkatan dan variabel lainnya bernilai tetap, maka dampaknya pada penurunan nilai ROA 0,0000315 dan tidak signifikan. Perputaran Piutang sebesar 0,0009508 artinya, jika variabel ini mengalami peningkatan dan variabel independen lainnya bernilai tetap, maka dampaknya pada peningkatan nilai ROA 0,0009508 yang juga tidak signifikan. Ukuran Perusahaan sebesar 0,0110033 artinya, jika variabel ini mengalami peningkatan dan faktor lainnya memiliki nilai constant, maka dampaknya pada peningkatan nilai ROA 1,100 persen dan juga tidak signifikan.

Koefisien determinasi atas model regresi diperoleh nilai sebesar 0,1688, artinya kontribusi ROA dipengaruhi sebesar 16,88 persen atas faktor Perputaran Modal Kerja, Perputaran Piutang serta Ukuran Perusahaan sebagai variabel kontrol, dan sisanya sebesar 83,12 persen ditentukan oleh faktor yang tidak diteliti. Nilai probabilitas signifikansi $\mathrm{F}$ diperoleh sebesar 0,5475. Hasil ini memiliki nilai yang lebih besar dari 0,05, artinya Perputaran Modal Kerja dan Perputaran Piutang tidak berdampak pada meningkatnya Return On Assets.

Nilai probabilitas signifikansi $\mathrm{t}$ diperoleh masingmasing sebesar 0,462 untuk Perputaran Modal Kerja (X1), 0,532 untuk Perputaran Piutang (X2) serta 0,384 untuk Ukuran Perusahaan. Ketiga probabilitas signifikansi ini menghasilkan nilai yang lebih besar dari 0,05, artinya masing-masing Perputaran Modal Kerja dan Perputaran Piutang tidak berdampak pada meningkatnya Return On Assets serta Variabel Ukuran Perusahaan tidak berfungsi sebagai variabel kontrol.

\section{Pembahasan}

Return On Assets atas Perputaran Modal Kerja dengan working capital turnover proksi (tabel 6) menghasilkan nilai koefisien regresi sebesar minus 0,0110033 dan probabilitas signifikansi sebesar 0,462, artinya Perputaran Modal Kerja yang meningkat dalam pengukuran ini tidak memberikan dampak pada nilai ROA ( $\mathrm{H}_{1}$ ditolak). Temuan penelitian ini perputaran modal kerja sejalan dengan penelitian (Rachmaniah, 2017) yang juga gagal memprediksi profitabilitas dengan ROE yang pada penelitian ini tidak berdampak pada Return On Assets.

Return On Assets atas Perputaran Piutang dengan receivables turnover proksi (tabel 6) menghasilkan nilai koefisien regresi sebesar minus 0,0000315 dan probabilitas signifikansi sebesar 0,384. Hasil ini menyatakan bahwa Perputaran Piutang yang meningkat dalam pengukuran ini juga tidak memberikan dampak pada nilai $\mathrm{ROA}\left(\mathrm{H}_{2}\right.$ ditolak). Temuan penelitian ini atas perputaran modal kerja yang sejalan dengan penelitian (Rachmaniah, 2017) yang juga gagal memprediksi profitabilitas dengan ROE yang pada penelitian ini tidak berdampak pada Return On Assets. Temuan penelitian ini perputaran piutang sejalan dengan penelitian tidak selaras dengan penelitian (Nginang, 2019) bahwa kinerja piutang untuk memulihkan atau percepatan dalam rangka memperoleh keuntungan.

Return On Assets atas Perputaran Modal Kerja dan Perputaran Piutang proksi (tabel 6) menghasilkan nilai probabilitas signifikansi $F$ sebesar 0,5475 . Hasil ini berarti bahwa Perputaran Modal Kerja dan Perputaran Piutang juga tidak memberikan dampak pada nilai $\mathrm{ROA}\left(\mathrm{H}_{3}\right.$ ditolak). Temuan penelitian ini perputaran modal kerja dan perputaran piutang tidak berpengaruh gagal membuktikan signifikansi profitabilitas dengan proksi ROE pada peneletian terdahulu, sementara sejalan dengan penelitian (Rachmaniah, 2017) atas masing-masing perputaran modal kerja, persediaan dan kas juga tidak berpengaruh secara signifikan terhadap profitabilitas dengan proksi ROE.

\section{SIMPULAN DAN SARAN}

\section{Simpulan}

Hasil penelitian dan pembahasan di atas memberikan simpulan penelitian yaitu:

1. Pengukuran perputaran modal kerja tidak berdampak pada meningkatnya Return On Assets

2. Pengukuran perputaran piutang tidak berdampak pada meningkatnya Return On Assets

3. Perputaran modal kerja dan perputaran piutang tidak berdampak pada meningkatnya Return On Assets

\section{Saran}

Saran penelitian ini adalah perusahaan dapat menggunakan rasio perputaran modal kerja lainnya seperti perputaran aset tetap serta perputaran piutang 
lainnya seperti rata-rata penagihan piutang dan ratarata sediaan pada gudang yang disimpan selama periode tertentu untuk menilai pengukuran efektifitas dan efisiensi pengelolaan modal kerja dan perputaran piutang dengan lebih baik. Peneliti selanjutnya diharapkan dapat menambah perusahaan lainnya pada jenis Industri Manufaktur Sektor Kimia dan Dasar lainnya agar dapat memperbaiki temuan pada penelitian ini serta menambahkan faktor lainnya sebagai pengukuran untuk mengidentifikasi profitabilitas, seperti corporate governace, rasio keuangan seperti leverage, earnings per share, dan proksi lainnya.

\section{DAFTAR PUSTAKA}

AKR. (2019). Annual Report PT AKR Corporindo Tbk.: Melangkah Maju dengan Strategi Jitu (Moving Forward with the RIGHT Strategy) dan Entitas Anaknya tanggal 31 Desember 2018. Jakarta: PT AKR Corporindo Tbk.

AKR. (2019). Sekilas PT AKR Corporindo. Retrieved Maret 8, 2019, from Media Informasi Kinerja Perusahaan Indonesia: http://annualreport.id/perusahaan/PT\%20AKR\%2 0CORPORINDO, \%20Tbk

Brigham, E., \& Houston, J. (2015). Fundamentals of Financial Management (14 ed.). (J. Sabation, Ed.) Boston: Cengage Learning.

Chakiki, N., \& Jawoto. (2016). Pengaruh Perputaran Piutang dan Perputaran Modal Kerja terhadap Likuiditas Perusahaan Consumer Goods. Jurnal Ilmu dan Riset Manajemen, 5(9), 1-15.

En, T. K., \& Sunarko, J. D. (2011). Peranan Sistem Informasi Akuntansi Penjualan Untuk Meminimalisasi Piutang Tak Tertagih (Studi Kasus Pada Perusahaan Sepatu "X"). Akurat Jurnal Ilmiah Akuntansi, 5(2).

Fahmi, I. (2017). Analisis Laporan Keuangan. Bandung: Alfabeta.

Gitman, L., \& Zutter, C. (2015). Principles of Managerial Finance (14 ed.). (D. Battista, Ed.) Boston: Prentice Hall.

Gunawan, A. (2012). Analisis Rasio Keuangan untuk Menilai Kinerja Keuangan PT Fajar Surya Wisesa, Tbk. Periode Tahun 2009, 2010 dan 2011. Akuntansi Perpustakaan. Yogyakarta: Universitas Negeri Yogyakarta.

Gustiady, D. (2018). Analisis Modal Kerja dalam Meningkatkan Profitabilitas pada PT. Perkebunan
Nusantara IV (Persero) Medan. Medan: FEB Universitas Muhammadiyah Sumatera Utara.

Husain, T. (2017). Analisis Determinan Faktor-Faktor Yang Mempengaruhi Niat Penggunaan Software Audit. Jurnal Ilmiah Matrik, 19(2), 131-150. https://doi.org/10.33557/jurnalmatrik.v19i2.381

Husain, T., Pasupati, B., \& Quintania, M. (2020). Prediction of Audit Quality Based on Financial Ratio's: Empirical Testing. International Journal of Advanced Scientific Technologies in Engineering and Management Sciences, 6(9), 1-5.

IDX. (2020). Listed Companies: Financial Statements \& Annual Report. Retrieved 2020, from Indonesia Stock Exchange:

https://www.idx.co.id/en-us/listedcompanies/financial-statements-annual-report/

Isfani, Y., Dewi, E. P., \& Husain, T. (2019). Relationships Accounting Treatment of Fixed Assets towards the Fairness of Reporting Financial Statements. European Exploratory Scientific Journal, 3(3), 1-12.

Kasmir, D. (2016). Analisis Laporan Keuangan. Jakarta: PT. Rajagrafindo Persada.

Kementerian ESDM. (2019, Juli 1). Hingga Tahun 2019, BBM Satu Harga Capai 162 Titik. Retrieved Juli 3, 2019, from Berita: https://migas.esdm.go.id/post/read/hingga-tahun2019-bbm-satu-harga-capai-162-titik

Khristiana, Y., \& Sapariyah, R. A. (2016). Kinerja Keuangan Perbankan Syariah dengan Dimensi Profitabilitas. BHIRAWA - Journal of Marketing and Commerce, 4(1), 31-40.

Lepădatu, G. (2010). The Importance of the Cost Information in Making Decisions. Knowledge Horizons - Economics, 2(3), 36-46.

https://econpapers.repec.org/RePEc:khe:journl:v:2 :y:2010:i:3:p:36-46

Lisdawati. (2020). Prediksi Corporate Value berdasarkan Ukuran Perusahaan dan Faktor Rasio Keuangan melalui Tanggung Jawab Sosial Perusahaan. Journal of Management Review, 4(2), 473-489.

Lisdawati, \& Khair, O. I. (2020). Analysis of Banking Industry Efficiency Level: A Study of LQ-45 Company in Indonesian Stock Exchange (IDX). European Exploratory Scientific Journal, 4(3), 20-26. http://dx.doi.org/10.25157/mr.v4i2.3450 
64 Coopetition, Vol XII, Nomor 1, Maret 2021, 55 - 64

(E-ISSN : 2615-4978, P-ISSN : 2086-4620)

Mailinda, R. (2018). Pengaruh Leverage, Likuiditas, dan Ukuran Perusahaan terhadap Profitabilitas pada BNI Syariah di Indonesia Periode 20152017. FEB Islam. Banda Aceh: UIN Ar-Raniry.

Murhadi, W. R. (2015). Analisis Laporan Keuangan: Proyeksi dan Valuasi Saham. Jakarta: Salemba Empat.

Nginang, Y. (2019). Analisis Tingkat Perputaran Piutang pada PT. Nippon Indosari Corporindo Tbk di Kota Makassar. Jurnal Economix, 7(1), 159-169.

Pasupati, B. (2020). The Impact of Accounting Conservatism on Corporate Equity Valuation Moderated by Good Corporate Governance. European Exploratory Scientific Journal, 4(2), 112.

Priyanto, A. A. (2019). Faktor-Faktor yang Mempengaruhi Return On Assets (ROA). Jurnal Ilmu Manajemen, 9(1), 64-75. https://doi.org/10.32502/jimn.v9i1.2117

Rachmaniah. (2017). Analisis Modal Kerja dan Profitabilitas PT. Berau Coal Energy Tbk. Ekonomia , 6 (2).

Ramadhan, K. D., \& Syarfan, L. O. (2016). Analisis Laporan Keuangan dalam Mengukur Kinerja Perusahaan pada PT. Ricky Kurniawan Kertapersada (Makin Group) Jambi. Jurnal Valuta, 2(2), 190-207.

Sakir, A., \& Zainul, Z. R. (2019). Are Foreign Investors Smarter than Domestic Investors? Empirical Evidence from Indonesia. 1st Aceh Global Conference (AGC 2018), Series: Advances in Social Science, Education and Humanities Research. 292, p. 2. Banda Aceh: Atlantis Press. https://doi.org/10.2991/agc-18.2019.61

Sani, A., Pusparini, N. N., R., R., Khristiana, Y., Zailani, A. U., \& Husain, T. (2020). E-Business Adoption Models in Organizational Contexts on The TAM Extended Model: A Preliminary Assessment. 8th International Conference on Cyber and IT Service Management (CITSM 2020). Pangkalpinang: UIN Syarif Hidayatullah. https://ieeexplore.ieee.org/abstract/document/9268 $869 /$

Sani, A., Wiliani, N., \& Husain, T. (2019). Spreadsheet Usability Testing in Nielsen's Model among Users of ITSMEs to Improve Company Performance. European Journal of Scientific Exploration, 2(6), 1-9.
Sanjaya, S., \& Rizky, M. F. (2018). Analisis Profitabilitas Dalam Menilai Kinerja Keuangan Pada PT. Taspen (Persero) Medan. KITABAH: Jurnal Akuntansi dan Keuangan Syariah, 2(2).

Santosa, A. D. (2020). Analisis Kuantitatif Menggunakan Stata (Cetakan Pertama). Yogyakarta: Kepel Press.

Sunardi, N., Husain, T., \& Kadim, A. (2020). Determinants of Debt Policy and Company's Performance. International Journal of Economics \& Business Administration (IJEBA), VIII(4), 204213. https://doi.org/10.35808/ijeba/580

Supranto, J., \& Limakrisna, N. (2019). Petunjuk Praktis Penelitian Ilmiah untuk Menyusun Skripsi, Tesis dan Disertasi (5 ed.). Bogor: Penerbit Mitra Wacana Media.

Sutrisno. (2013). Manajemen Keuangan Teori, Konsep, dan Aplikasi. Jakarta: Ekonisia.

Triatika P., D., Lestari, T., \& Rasyidi, A. (2016). Penerapan Sistem Informasi Akuntansi Penjualan Kredit sebagai Alat Pengendalian Intern Perusahaan CV. Verotech Technocal Supply di Surabaya. E-Journal Akuntansi "EQUITY", 2(3), 238-247.

Zailani, A. U., Husain, T., \& Budiyantara, A. (2020). Analisis Simulasi Sistem Penunjang Keputusan: Model Matematis Dengan Pendekatan Goodnessof Fit Berbasis Structural Equation Model. SMARTICS Journal, 6(1), 10-16 https://doi.org/10.21067/smartics.v6i1.4157. 